\title{
Francisco Ruiz Ramón: amigo y maestro ${ }^{1}$ \\ Francisco Ruiz Ramón: Friend and Mentor
}

\author{
Luciano García Lorenzo \\ CSIC, Madrid \\ ESPAÑA \\ luciano.garcia@cchs.csic.es
}

[Hipogrifo, (issn: 2328-1308), 5.1, 2017, pp. 9-12]

DOl: http://dx.doi.org/10.13035/H.2017.05.01.02

Francisco Ruiz Ramón (Játiva, Valencia, 1930) murió el 17 de enero de 2015 en Tampa, Estados Unidos, aunque estamos seguros que no hubiera sido este el lugar elegido si hubiera tenido la oportunidad de hacerlo.

Ruiz Ramón se doctoró en la Universidad Complutense de Madrid con una tesis sobre Pérez Galdós que se convirtió en libro en 1964. Fue Lector en la Universidad de Oslo (1957-1963), Assistant profesor y Associated en la de Puerto Rico-Río Piedras (1963-1967), después Associated profesor y Professor en la de Indiana-Purdue (1968-1983), más tarde Professor en la de Chicago (1983-1987) y, finalmente, Centennial Professor en Vanderbilt University (1987-1992).

Amigo, maestro, compañero, Paco Ruiz Ramón ha sido una de las personas que más influencia han tenido en la evolución de los estudios sobre el teatro español. Aunque el listado que podríamos ofrecer para justificar nuestra afirmación sería extenso, queremos detenernos en tres aspectos fundamentales y reconocidos por la profesión desde hace muchos años. En primer lugar, siguiendo un criterio cronológico, Ruiz Ramón comienza sus aportaciones al teatro clásico español con un libro que está publicado por la editorial que más influencia ha tenido en el mundo del libro y de la lectura en España en las últimas décadas. Nos referimos a Alianza editorial y a su colección de bolsillo, donde Ruiz Ramón ofrece su versión de El Duque de Viseo y con este texto el testimonio de una de sus preocupaciones más evidentes. Nos referimos a la práctica trágica por parte de nuestros escritores clásicos y que Ruiz Ramón va a confirmar inmediatamente con los tres volúmenes

1. Doy las gracias a Ignacio Arellano por haber acogido este Homenaje entre las publicaciones que dirige. Y, por supuesto, a Mariela Insúa. Con ella al lado todo ha sido muy fácil. 
que, entre 1967 y 1969, consagra a la edición de diez tragedias calderonianas, los numerosos trabajos publicados en revistas y Actas de congresos, como asimismo con el volumen Calderón y la tragedia, aparecido en 1984.

La segunda, e importantísima, aportación de Ruiz Ramón fue su Historia del teatro español, primero con el volumen consagrado al teatro hasta 1900 (1967) y en segundo lugar el dedicado a lo que se había escrito durante más de la mitad del siglo XX (1971). Esta Historia del teatro no hace falta recordar que ha sido para varias generaciones de profesores y estudiantes el insustituible libro de cabecera que ha ayudado durante décadas a mejor entender nuestro teatro, llamando, sobre todo, la atención dos de las más importantes preocupaciones del maestro: la contemporaneidad de los clásicos en la lectura y en la escena y la defensa de los mejores textos escritos en el siglo XX, sobre todo de los autores cronológicamente más cercanos a él. Sobre lo primero escribió en 1988: «Si los ingleses han sabido leer - para la escena- contemporáneamente a su Shakespeare y hacer que todos conectemos hoy profundamente con sus textos; si los franceses han sabido también leer y hacernos ver a su Moliére, su Corneille y su Racine como nuestros, contemporáneos de nuestros deseos, nuestras obsesiones o nuestras frustraciones, ¿por qué los españoles o, mejor, los hispanos de ambos mundos, no hemos sabido hacer lo mismo con nuestro Lope, nuestro Tirso o nuestro Calderón? ¿Por qué no los leemos y los damos a ver, a nosotros mismos y a los demás, conectados con nuestros miedos, nuestras esperanzas o nuestras pulsiones?». Y antes, en 1977, Ruiz Ramón ya había afirmado: «Que nuestros hombres de teatro empiecen, pues, a perderles el respeto como textos muertos, para respetarlos como textos vivos».

El tercer núcleo de las aportaciones de Ruiz Ramón que es necesario destacar tiene como protagonistas las decenas y decenas de páginas con Calderón como centro de sus reflexiones. Sin duda, el trabajo de Ruiz Ramón sobre el autor de La vida sueño está unido al de otros especialistas o al Congreso celebrado en Madrid, en 1981, para entender, como se ha señalado repetidamente, que esos nombres y aquella reunión marcaron un antes y un después en el acercamiento a la producción teatral de don Pedro y que, de una manera inequívoca, llega hasta nuestros días.

Todo lo afirmado, por supuesto, es solo parte del trabajo investigador -profundidad y rigor envidiables - de un hombre enamorado del teatro y para el cual fue actor, autor, espectador serio y ecuánime y estudioso ilusionado siempre. Supo ser, como a él le gustaba decir, amigo de sus amigos y hermano de quienes lo teníamos como un hermano mayor. Y, por supuesto, siempre a su lado, Genoveva.

El presente volumen acoge una treintena de artículos escritos por colegas y discípulos de Francisco Ruiz Ramón. Trabajos sobre autores y obras de géneros diferentes, como también lo hizo Paco. Quiero dar las gracias a todas estas personas por su positiva respuesta a mi petición y, sobre todo, por su su reconocimiento y recuerdo al maestro. 


\section{PUBLICACIONES}

Monografías

Tres personajes galdosianos. Ensayo de aproximación a un mundo religioso y moral, Madrid, Revista de Occidente, 1964.

Historia del teatro español (desde sus orígenes hasta 1900), Madrid, Alianza Editorial, 1967 (varias ediciones posteriores). Editorial Cátedra, 1979 (varias ediciones posteriores).

Historia del teatro español. Siglo XX, Madrid, Alianza Editorial, 1971 (varias ediciones posteriores). Editorial Cátedra, revisada y ampliada, 1976 (varias ediciones posteriores).

Estudios de teatro español clásico y contemporáneo, Madrid, Fundación Juan March/Editorial Cátedra, 1978.

Calderón y la tragedia, Madrid, Alhambra, 1984.

Celebración y catarsis. Leer el teatro español, Murcia, Universidad de Murcia, 1988.

América en el teatro clásico español. Estudio y textos, Pamplona EUNSA, 1993.

Paradigmas del teatro clásico español, Madrid, Cátedra, 1997.

Calderón nuestro contemporáneo. El escenario imaginario, Madrid, Castalia, 2000.

Teatro español. Kauderon de ra baruka seitan yonhyakunen kinen koen, edición en japonés y español, Tokio, Universidad de Tokio, 2002. Serie Cultura Hispánica, 8.

Libro coordinado

El mito en el teatro clásico español. Ponencias y debates de las VII Jornadas de teatro clásico español. Festival de Almagro, 1984, coordinación de Francisco Ruiz Ramón y César Oliva, Madrid, Taurus, 1988.

\section{Ediciones}

Lope de Vega. El Duque de Viseo, Madrid, Alianza Editorial, 1966.

Pedro Calderón de la Barca. Tragedias, Madrid, Alianza Editorial, 1967-1969, 3 vols.

Pedro Calderón de la Barca. La vida es sueño. El Alcalde de Zalamea, Barcelona, Salvat, 1970. Segunda ed. 1992.

José Martín Recuerda. Las salvajes en Puente San Gil. Las arrecogías en el Beaterio de Santa María Egipciaca, Madrid, Cátedra, 1977 (ediciones posteriores).

Pedro Calderón de la Barca. La Cisma de Inglaterra, Madrid, Castalia, 1981. 
Pedro Calderón de la Barca. La hija del aire, Madrid, Cátedra, 1987.

Lope de Vega. Fuenteovejuna, Salamanca, Publicaciones del Colegio de España, 1991.

Pedro Calderón de la Barca. La hija del aire (Segunda parte). La cisma de Inglaterra, en Pedro Calderón de la Barca. Obras maestras, Madrid, Castalia, 2000.

Pedro Calderón de la Barca. El médico de su honra. La cisma de Inglaterra. Edición la primera de D. W. Cruickshank y de Francisco Ruiz Ramón la segunda, Madrid, Castalia, Biblioteca Clásica Castalia, 2001. Se trata de las dos obras publicadas en la Colección Clásicos Castalia.

Obras teatrales

Nupcias, Revista de Occidente, 28, 1965, pp. 72-86.

El Inquisidor, Barcelona, Salvat, 1989.

Juego de espejos, Madrid, Fundamentos, 1991.

Retablo de Indias, Madrid, Asociación de directores de escena de España, 1992.

Obra narrativa

Missis Adams, pitonisa, Premio Gabriel Miró, Alicante, Caja de Ahorros de Alicante y Murcia, 1982. 